\section{Journal of Global \\ Management Sciences}

Vol. 3, $\mathrm{N}^{\circ} 2,2020$

\title{
Management by labor competencies in the District Municipality of Santa Lucía, Lucanas - Ayacucho, 2019 [Gestión por competencias laborales en la Municipalidad Distrital de Santa Lucía, Lucanas - Ayacucho, 2019]
}

\author{
Alejandro Alfredo Quispe Mayuri \\ Universidad Privada San Juan Bautista, Lima, Peru. \\ Alejandro.Quispe@upsjb.com.pe
}

Received: 12 August 2020; Accepted: 26 August 2020; Published: 06 September 2020

\section{Resumen}

Este artículo presenta los argumentos necesarios que permitan visualizar las competencias laborales como un requerimiento para el logro del desarrollo personal y profesional. Con ello, poder mejorar la gestión de la organización que requiere de los empleados para enfrentar las exigencias de su entorno y lograr objetivos establecidos. Se concluye que existe un reto importante de adecuarse a las exigencias del contexto y a los cambios del entorno, a las crecientes necesidades de los usuarios, siendo necesario adaptar un sistema de gestión por competencias en busca alcanzar el crecimiento y desarrollo organizacional para mejorar el desempeño de los empleados. Y asimismo este desarrollo tiene su punto de partida en la mejora continua de las actitudes y aptitudes de los empleados, específicamente en las competencias.

Palabras clave: Gestión por competencias, Dirección de personal, Municipality.

\begin{abstract}
This article presents the necessary arguments that allow the visualization of labor competencies as a requirement for the achievement of personal and professional development. With this, to be able to improve the management of the organization that requires employees to face the demands of their environment and achieve established objectives. It is concluded that there is an important challenge to adapt to the demands of the context and to the changes in the environment, to the growing needs of users, being necessary to adapt a management system by competencies in order to achieve organizational growth and development to improve the performance of the employees. And also this development has its starting point in the continuous improvement of the attitudes and aptitudes of the employees, specifically in the competences.
\end{abstract}

Keywords: Management by competencies, Personnel management, Municipality.

\section{Introduction}

The importance of labor competencies in the public sector is necessary to: identify the competencies of the people who do management, those that must be developed and those that need to be strengthened over time with the intention of achieving a more efficient and sustainable strategic management. It is established that these competencies are a different alternative to promote higher performance at work and motivation, among other aspects, is what constitutes 
Vol. 3, $\mathbf{N}^{\circ}$ 2, 2020

\section{GMS \\ Journal of Global Management Sciences}

Copyright @ 2020, CINCADER.

ISSN 2663-0753

DOI: https://doi.org/10.32829/gms.v3i2.176
A publication of CINCADER

Centre of Research and Training for

Regional Development

Online at www.journals.cincader.org

the purpose of the application of the Competency Management model. This article aims to contribute to the systematization of knowledge on the subject, describing in this sense a series of facets related to the conception of competences.

It is relevant to establish a management system by competencies as a development and change strategy in the Municipality, so that it influences the work performance of municipal employees (Quintanilla, 2008). The municipality fulfills the role of promoting local development, it has to act as an integrating and strategic planning institution; Furthermore, it must be receptive and understandable within a comprehensive and accessible organizational culture, which implies efficient communication with citizens and a position sensitive to needs insofar as it is called upon to meet the demands of the population, as well as act as a local provider promoting the active participation of organized citizens (Aguilar, 2008).

Management by competence today is not only based on some elements such as technology and information; but also in the capacities or skills (talent). What is needed today is to get rid of the paradigms that prevent change and enter the adventure of changing, constantly innovating, facing the future, since the main protagonist is the person (human talent); and the success or failure of the organization will depend on their decisions (Casa, 2015).

Competency assessment is a tool to identify improvements in human talent in organizations through behavioral indicators; performance evaluation by competencies measures the results to be achieved, the fulfillment of objectives, levels of knowledge, skills and behaviors that contribute to the achievement of business objectives (Arizaga \& Jativa, 2016). It has been determined that the process of training by competencies and the work performance of the workers of the Bioalimentar company are the main methods used to develop competencies, following the suggestions of the respondents (Marino, 2018).

A study was carried out on the management of labor competencies in the professionals of the Villa Rica District Municipality, considering some study dimensions such as: planning, decisionmaking, teamwork, ethical commitment, creativity and initiative are highly related to performance labor of workers. Outstanding dimensions were found in terms of competencies; $58.3 \%$ present a moderate percentage in planning their activities, this being part of every person linked to the public or private administration carry out said process. $59.5 \%$ work as a team, ensuring that the institution achieves its planned objectives and $54.8 \%$ have initiative when carrying out their work; Which shows that they do not expect to receive orders from their boss; rather, they begin to perform their usual job functions; both presented moderate percentages (Sinchi, 2020).

In the district Municipality of Santa Lucía, it does not have a human resources area to carry out the recruitment process and the selection of personnel according to what is established in the Personnel Assignment Chart, and as a consequence there is a lack of specialized personnel to perform this process. The lack of suitable personnel is also appreciated and they show substantial deficiencies when carrying out their work, which causes the user to receive a deficient service, generating complaints and claims on their part. In addition, individual work is encouraged and not in a team, where everyone carries out their activities under a short-term approach. It is also generating little motivation, little commitment to the institution, poor capacity building and teams, elements that are necessary for long-term strategic management. Likewise, Municipal Law No. 27972, of the Organization and Functions Manual, and the Organization and Functions Regulation of the institution, where it erroneously involves the councilors in administrative activities that are not within its competence, being its function, purely supervisory. It is also appreciated that there are difficulties in the development of the channels, which interferes with the fluid communication between the officials and collaborators of this institution, originating a deficient coordination and communication between the bosses and collaborators, in addition to not having timely information for the taking immediate decisions. Another difficulty is not having 


\section{GMS \\ Journal of Global Management Sciences}

Vol. 3, $\mathrm{N}^{\circ}$ 2, 2020
Copyright @ 2020, CINCADER.

ISSN 2663-0753

DOI: https://doi.org/10.32829/gms.v3i2.176

internet access, which has forced the installation of a liaison office in the city of Nazca, making integration with the staff working in both offices and teamwork more difficult, and the situation is complicated because it lacks computer systems that allow the flow of procedures in all its areas. Competencies in work activities are reflected in actions such as: assuming responsibilities, decision-making capacities, service provision, performance at work, attitudes, skills, knowledge and experiences that individuals exercise in order to collaborate in the efforts of the company to achieve its objectives (Mulder, 2007).

The creation of a work environment in which opportunities for growth and development are present is relevant. Organizations are focused on the incorporation of new strategies to be competitive and that their employees possess the knowledge, abilities and skills that enable them to stay in the job market and competently develop their production processes. These processes are increasingly demanding and require a greater degree of innovation and creativity to generate a better competitive level (Rahman et al., 2006).

\section{Materials and methods}

The type of Applied research was developed, considering the application of knowledge to generate new knowledge. In turn, the research level was Descriptive-correlational, because it allowed us to know specific features of the population under study and establish the relationship between them (Hernández, 2006; Arias, 2006). The study took into account the employees of the administrative part of the District Municipality of Santa Lucía, who are in their entirety 12. Using the census-type convenience sampling, surveying all employees of the administrative area (Ávila, 2001). The survey was used as the data collection technique, and its instrument was the questionnaire, which was developed taking into consideration the study dimensions, which were: i) Identification of skills and competencies, with four items. ii) Teamwork, with four items. iii) Internal communication, with four items.

\section{Results}

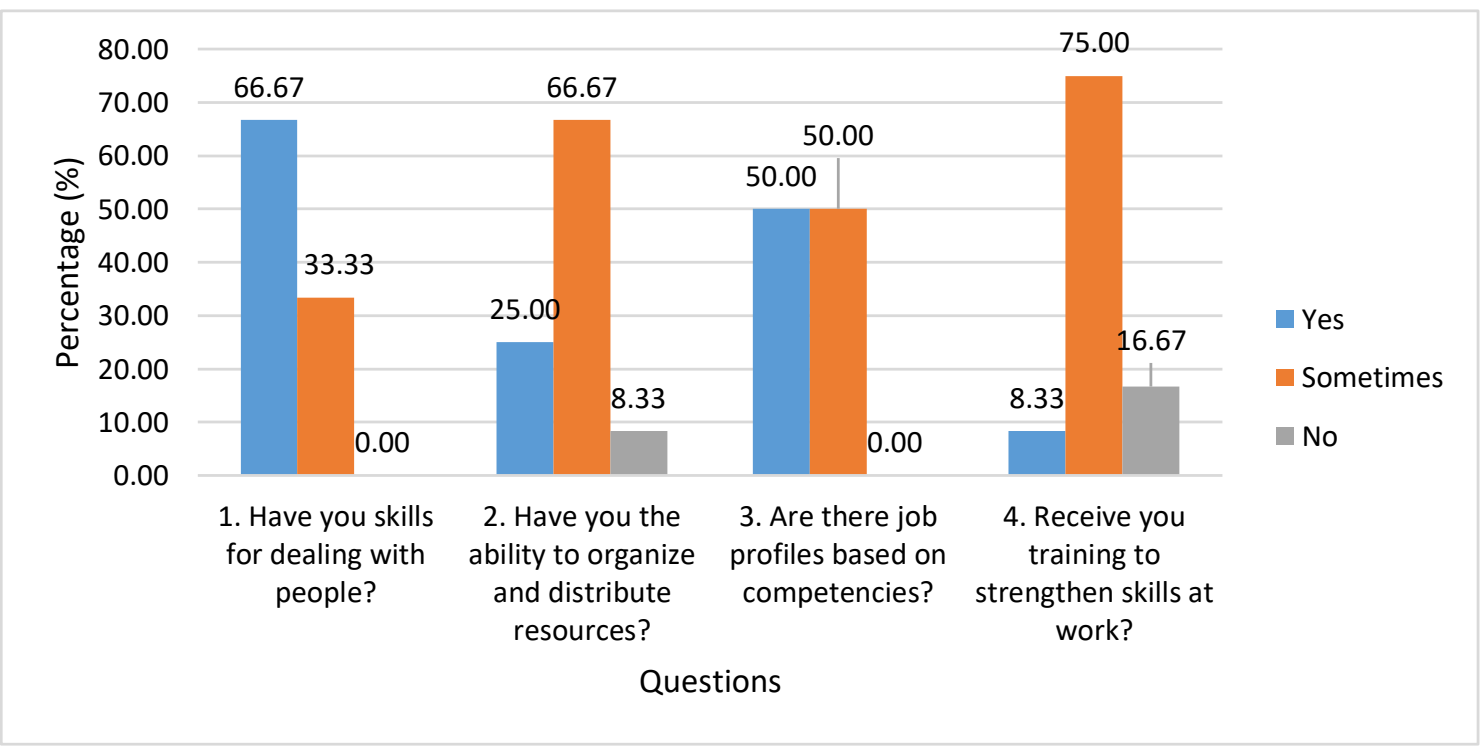

Figure 1. Identification of skills and competences dimension 


\section{GMS \\ Journal of Global Management Sciences}

Vol. 3, $\mathrm{N}^{\circ}$ 2, 2020
Copyright @ 2020 , CINCADER.

ISSN 2663-0753

DOI: https://doi.org/10.32829/gms.v3i2.176

\section{CINCADER}

Centre of Research and Training for

Regional Development

Online at www.journals.cincader.org

\section{Analysis of the Dimension identification of capacities and competences.}

It is determined by the skills for dealing, ability to organize and distribute, personnel selection, job profiles, on-the-job training.

In relation to the skills indicator for dealing with people, $66.67 \%$ of the employees stated that if they possess these skills and a favorable situation is appreciated, $33.33 \%$ established that they emerge sometimes.

In relation to the indicator capacity to organize and distribute resources, $25.0 \%$ of the employees stated that yes, they have developed this capacity and an unfavorable situation is appreciated, $66.67 \%$ established that these competencies are applied sometimes and $8.33 \%$ said they have not developed this ability.

In relation to the indicator existence of job profiles based on competencies, $50.0 \%$ of the employees stated that yes, a more or less favorable situation exists and a more or less favorable situation is appreciated, $50.0 \%$ established that these profiles are sometimes applied.

Regarding the indicator if they receive training to strengthen their competencies at work, $8.33 \%$ of the employees stated that yes, an unfavorable situation is appreciated, $75.0 \%$ stated that sometimes personnel are trained, and $16.67 \%$ I express that on-the-job training is not developed.

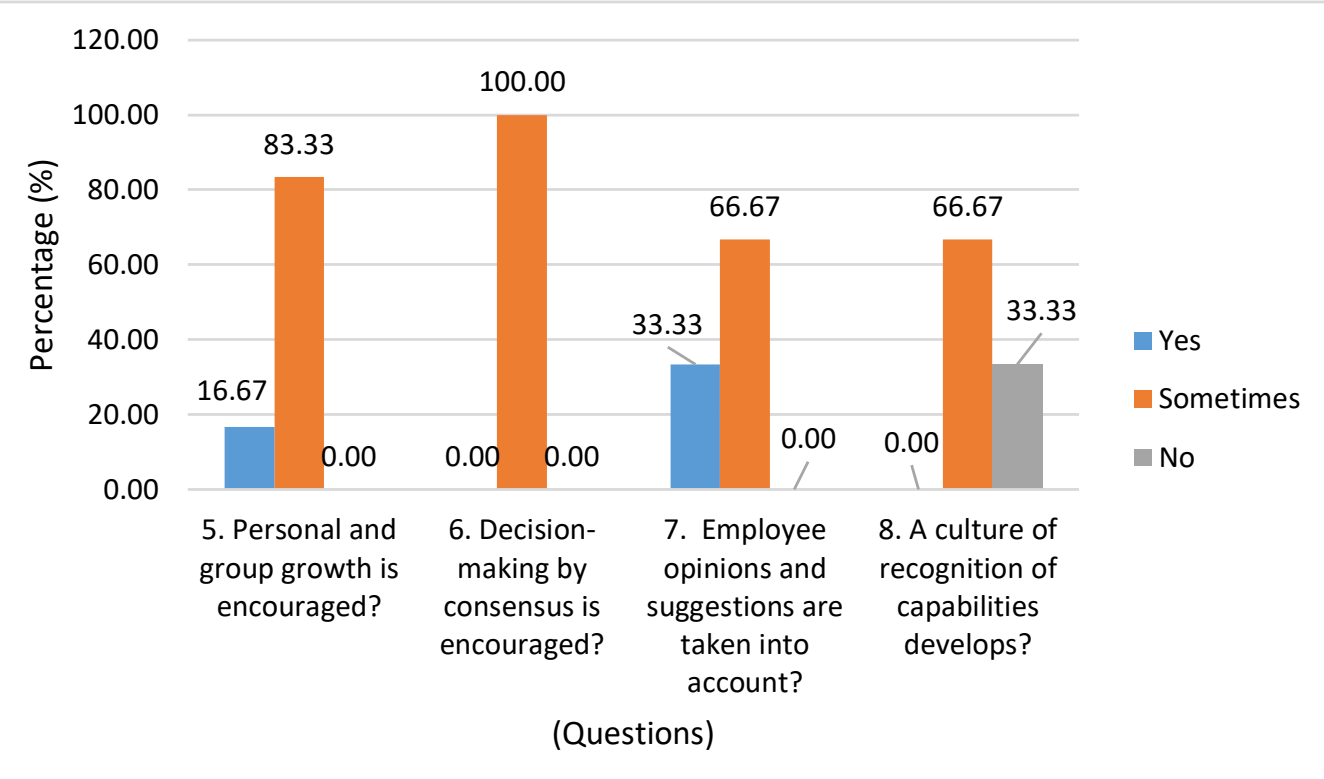

Figure 2. Teamwork dimension

Analysis of the teamwork dimension.

It is determined by personal and group growth, decision-making by consensus, taking into account the opinions and suggestions of employees, development of a culture of recognition.

In relation to the personal and group growth indicator, $16.67 \%$ of the employees stated that yes, this growth is fostered, and $83.33 \%$ stated that sometimes an unfavorable situation is appreciated. Regarding the indicator, decision-making by consensus, it is established that $100.0 \%$ of the employees stated that sometimes, a totally unfavorable situation was appreciated. 


\section{GMS \\ Journal of Global Management Sciences}

Vol. 3, $\mathrm{N}^{\circ}$ 2, 2020
Copyright @ 2020, CINCADER.

ISSN 2663-0753

DOI: https://doi.org/10.32829/gms.v3i2.176

In relation to the indicator, taking into consideration the opinions and suggestions of the employees, it is established that $33.33 \%$ of the employees said yes, appreciating a totally unfavorable situation and $66.67 \%$ said that sometimes.

Regarding the indicator, development of a culture of recognition of capabilities, it is established that $66.67 \%$ of the employees stated that sometimes, appreciating a totally unfavorable situation and $33.33 \%$ expressed that they were not.

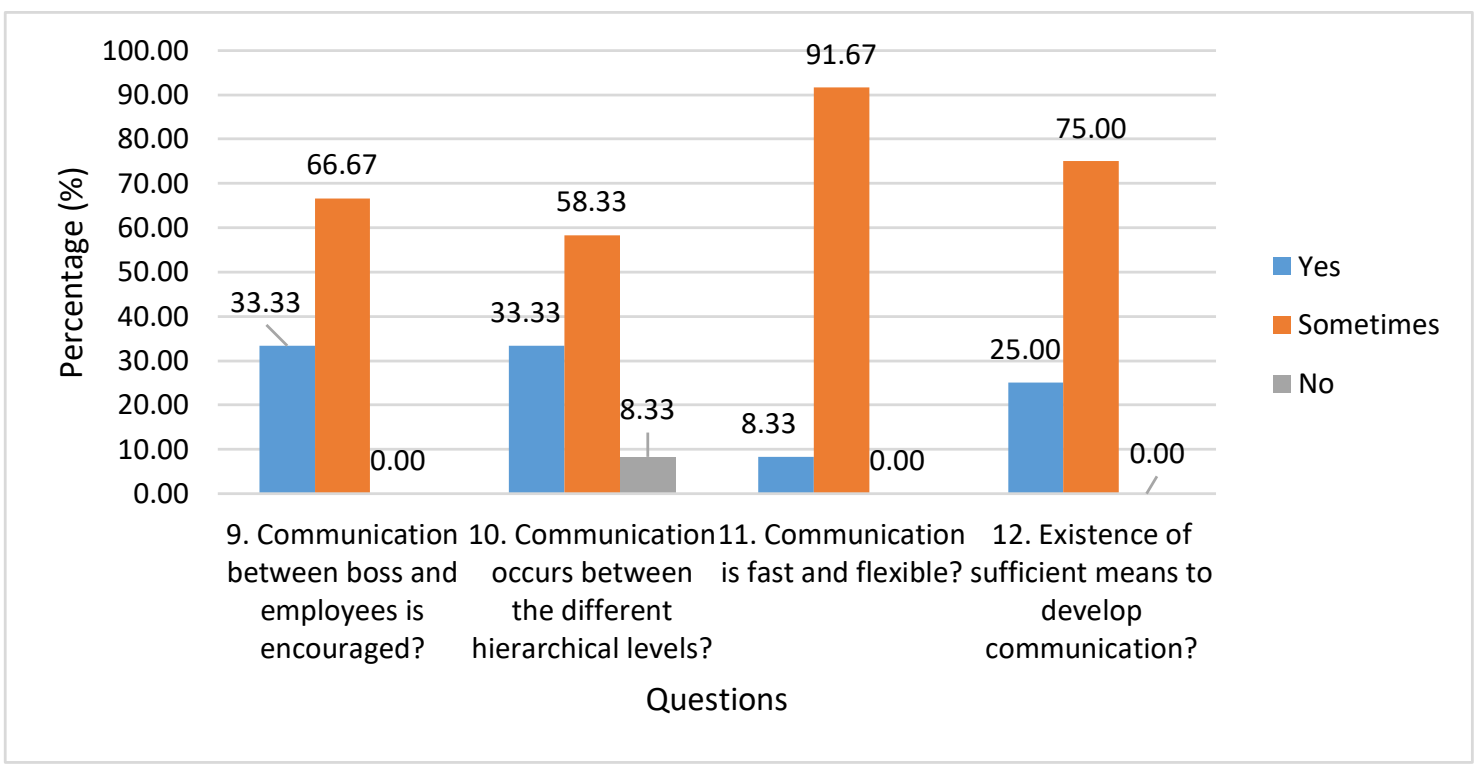

Figure 3. Internal communication dimension

\section{Analysis of the internal communication dimension.}

It is determined by the communication between boss and employee, communication between hierarchical levels, fast and flexible communication, means for the development of communication.

In relation to the indicator communication between boss and employee and vice versa, $33.33 \%$ of employees stated that yes, this communication occurs and $66.67 \%$ established that sometimes, appreciating an unfavorable situation.

Regarding the communication indicator between the different hierarchical levels, $32.33 \%$ of the employees stated that yes, this type of communication occurs, $58.33 \%$ stated that sometimes, and $9.33 \%$ said no, appreciating a situation unfavorable.

Regarding the fast and flexible communication indicator, $8.33 \%$ of employees stated that yes, communication has these characteristics, $91.67 \%$ expressed that sometimes, appreciating an unfavorable situation.

Regarding the indicator, sufficient means to develop communication, $25.0 \%$ of the employees stated that yes, they have these means, and $75.0 \%$ stated that sometimes, appreciating a totally unfavorable situation.

\section{Conclusions}

- It is concluded that in the dimension identification of capacities and competences, $66.67 \%$ express that if they have skills to deal with people, an important aspect because the orientation of the municipality is the attention to the user, in relation to the use of the ability 
Vol. 3, $\mathbf{N}^{\circ}$ 2, 2020

\section{GMS \\ Journal of Global Management Sciences}

Copyright @ 2020, CINCADER.

ISSN 2663-0753

DOI: https://doi.org/10.32829/gms.v3i2.176
A publication of

Centre of Research and Training for

Regional Development

Online at www.journals.cincader.org

to organize and distribute resources, $66.67 \%$ said that sometimes they develop this capacity, because employees are rarely given autonomy at work, $50.0 \%$ said that if job profiles are used based on competencies, that is to say that only on some occasions is this criterion used for the selection of personnel, and also that $75 \%$ express that training aimed at strengthening labor competencies is only sometimes received.

- It is concluded that in the teamwork dimension, $83.33 \%$ established that sometimes personal and group growth is encouraged, a negative aspect because it does not generate commitment to the organization and less identification with the task, also that $100 \%$ express that they do not The participation of employees in decision-making is encouraged, due to the fact that decision-making is centralized, also that $66.67 \%$ said that the opinions of employees are not accepted, an aspect that limits participation and group cohesion, In addition to not having a system of incentives and job recognition and also $66.67 \%$ of respondents said that sometimes the culture of recognition develops.

- It is concluded that in the internal communication dimension, $75 \%$ of the respondents expressed that communication between boss and collaborator is sometimes promoted and vice versa, a negative aspect because communication has to take place in every sense, whether vertical, horizontal and transversal. 58.33\% expressed that sometimes serious deficiencies are observed in communication between the different hierarchical levels, $91.67 \%$ said that only sometimes fast and flexible communication is achieved and $75.0 \%$ said that sometimes there are sufficient means to develop effective communication.

\section{References}

Aguilar, I. 2008. Gestión de la calidad en los municipios mexicanos. Un estudio de caso: Ecatepec de Morelos, México, 2003-2006. http://www.clad.org/siare isis/fulltext/0059402.pdf.

Arias, F. 2006. El proyecto de investigación: Introducción a la investigación científica (5ta ed.). Caracas, Venezuela: Editorial Episteme, C.A.

Arizaga Proaño, F. J., Jativa Enríquez, S. C. 2016. Análisis de la correlación de la evaluación del desempeño laboral por competencias y la evaluación del potencial con información recopilada por una empresa consultora. Pontificia Universidad Católica del Ecuador, Quito. http://repositorio.puce.edu.ec/bitstream/handle/22000/11230/TESIS\%20CORRELACI\%C 3\%93N\%20AR\%C3\%8DZAGA\%20- \%20J\%C3\%81TIVA.pdf?sequence=1

Ávila, R. 2001. Metodología de la Investigación. Lima - Perú: Editorial estudios y ediciones R.A.

Casa, M. 2015. Gestión por competencias y desempeño laboral del personal administrativo en la Municipalidad Distrital de San Jerónimo - 2015. Tesis de Licenciatura. Universidad Nacional José María Arguedas.

Hernández, S. et al. 2006. Metodología de la Investigación. Editorial McGraw Hill Interamericana. Colección 4a Edición.

Mariño Villafuerte, T. J. 2018. Diseño de un sistema de capacitación por competencias para mejorar el desempeño laboral; Tesis de Maestría, Universidad Técnica de Ambato, http://repositorio.uta.edu.ec/jspui/bitstream/123456789/28316/1/40\%20GTH.pdf.

Mudler, M. 2007. Competencia: la esencia y la utilización del concepto en la formación profesional inicial y permanente. Revista Europea de Formación Empresarial. Universidad de Wageningen, 40, 5 - 24.

Quintanilla, k. 2008. Gestión por competencias y desempeños laborales en las municipalidades de Ayacucho. Tesis de Licenciatura. Universidad Nacional De San Cristóbal de Huamanga.

Rahman, N., Molina, U., Parra, S. et al. 2006. Competencias laborales: un análisis desde Trabajo Social 1995 - 2005. Tendencias y Retos. Revista de la Facultad de Trabajo Social, Universidad La Salle Colombia, 11, 153 - 168. 
Vol. 3, $\mathbf{N}^{\circ} 2,2020$

Copyright $\odot 2020$, CINCADER.

ISSN 2663-0753

DOI: https://doi.org/10.32829/gms.v3i2.176

Sinchi, A. 2020. Las competencias y desempeño laboral de los trabajadores de la municipalidad distrital de Villa Rica. Tesis de Licenciatura. Universidad Nacional Agraria de la Selva. Tingo María.

\section{annexed}

\section{Questionnaire}

\begin{tabular}{|l|l|l|l|}
\hline \multicolumn{1}{|c|}{ Dimension: identification of capacities and competences } & Yes & Sometimes & No \\
\hline 1. Have you skills for dealing with people? & & & \\
\hline 2. Have you the ability to organize and distribute resources? & & & \\
\hline 3. Are there job profiles based on competencies? & & & \\
\hline 4. Receive you training to strengthen skills at work? & & & \\
\hline \multicolumn{1}{|c|}{ Dimension: Teamwork } & & & \\
\hline 5. Personal and group growth is encouraged? & & & \\
\hline 6. Decision-making by consensus is encouraged? & & & \\
\hline 7. Employee opinions and suggestions are taken into account? & & \\
\hline 8. A culture of recognition of capabilities develops? & & \\
\hline \multicolumn{1}{|c|}{ Dimenternal communication } & & \\
\hline 9. Communication between boss and employees is encouraged? & & & \\
\hline 10. Communication occurs between the different hierarchical levels? & & & \\
\hline 11. Communication is fast and flexible? & & & \\
\hline 12. Existence of sufficient means to develop communication? & & & \\
\hline
\end{tabular}

